\title{
The Relations of Job Type, Smartphone Usage, Religion, and Financial Institution Product Awareness
}

\author{
Moch. Edman Syarief ${ }^{1, *}$ Ira Novianty ${ }^{1}$ Ahmad Sirri ${ }^{1}$ \\ ${ }^{1}$ Accounting Department, Politeknik Negeri Bandung, Indonesia \\ *Corresponding author. Email: moch.edman@polban.ac.id
}

\begin{abstract}
This study aims to see the relationship between job type and the knowledge about Islamic financial institution products, either directly or through the intervening variable of smartphone usage. It also explores the role of religion as a moderating variable between these two aspects. The data were collected from the results of the questionnaires distributed via the Google Form service. These data were processed using the partial least squares approach. The findings show that job type affects the knowledge about Islamic financial institution products. The use of smartphones weakly affects the awareness about Islamic financial institution products. It shows that smartphones are not used as information support for the products of Islamic financial institutions. The study also finds that religion has a significant impact on the relationship between job type and awareness about Islamic financial institution products.
\end{abstract}

Keywords: Job Type, Religion, Smartphone Use, Product Awareness, Islamic Financial Institution.

\section{INTRODUCTION}

The product of Islamic financial institutions is generally a product that is consistent with the teachings of the Qur'an and hadith with the aim of bringing benefits both in this world and in the hereafter. Even though it is based on Islamic teachings, this product can be used by the public regardless of their religion. Products of Islamic financial institutions are essentially based on profitsharing in various forms and do not use the interest system (known as an interest-free bank) [1]. Thus, knowledge about the products of Islamic financial institutions is necessary in order for people not to expect interest but share profits [2].

A study from [3] states that the people in Samarinda consider Islamic financial institutions, especially Islamic banking, to be an alternative after conventional banking. This is in line with the opinion of [4] which states that urban communities are more open to Islamic retail banks, but [4] do not find that religion moderates the relative advantages, compatibility, and complexity of the desire to use Islamic retail banks, although it remains an element determinant to influence the desire to use Islamic retail banks.

Based on the search for interest through Google Trends for the topic of sharia cooperatives, sharia banking, and conventional banking, it appears that people in East Kalimantan still prefer conventional banking (yellow line) compared to sharia cooperatives (blue line) and Islamic/sharia banking (red line).

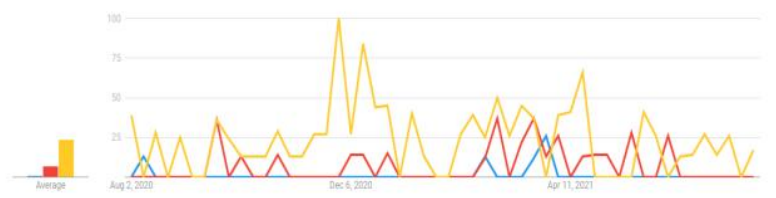

Figure 1 Trends in the search for sharia cooperatives, sharia banking, and conventional banking

This inclination illustrates that urban communities that are more open to technological developments can lead to the same trend, preferring conventional banking to Islamic financial institutions. This condition will be an obstacle to the development of Islamic financial institutions in East Kalimantan, especially in Samarinda.

Individuals who work in the Islamic banking environment, of course, have sufficient knowledge about the products of Islamic financial institutions [5], but this cannot be generalized to those who have jobs outside the environment of Islamic financial institutions. Research from [6] proves this.

Further, it is now possible to rapidly acquire knowledge or information about anything using 
smartphones [7]. Smartphones can also improve the performance of bank employees in providing information to customers and prospective clients [8]. The use of smartphones in the workplace can increase autonomy, enhance relationships with colleagues and superiors, and increase knowledge sharing among them. Other researchers state that the use of smartphones in the workplace can have both positive and negative consequences [9]. In addition, smartphones can also be used by the elderly who use them for accessing social media or reading news [10].

Based on the above description, this study is carried out to (1) observe how people from different professions perceive the products of Islamic financial institutions, (2) know whether smartphones can serve as a mediator for the public to acknowledge the products of Islamic financial institutions, and (2) discover whether religion plays a moderating role between the type of job and the knowledge about Islamic financial institution products.

\subsection{Related Work}

\subsubsection{Islamic Financial Institution Product}

According to [1], the products of Islamic financial institutions are inseparable from the principles of ijarah, murabaha, mudharaba, and musharaka. Some examples of these products are salam and istisna [11]. The profitsharing system is always applied to every product of Islamic financial institutions.

\subsubsection{Job Type}

[2] states that one's job has a relationship with his knowledge of banking products. However, this only applies to those who have a lot to do with banking activities [13], [14] while those who are engaged in other fields, apparently do not have sufficient knowledge about banking products [6].

\subsubsection{Smartphone Use}

The use of mobile internet can increase worker productivity [17]. [18] states that smartphones in the workplace can be used to share knowledge. Further, [8] explains that in this context, people use smartphones to share information about financial institution products.

\subsubsection{Religion}

In Malaysia, many Muslim and non-Muslim communities want Islamic banking products [20]. Thus, [4] states that religion does not moderate the intention to use Islamic banks, but [19] state that Muslim students have better financial knowledge than non-Muslim students.

\subsection{Our Contribution}

This study contributes to empirically explaining the role of religion in moderating the relationship between job type and knowledge of Islamic financial institution products. This study states that religion can increase public knowledge of Islamic financial institution products. The consequence is that the Muslim community must strengthen religious education in order to increase their financial knowledge in general and the knowledge about Islamic financial institution products in particular. This condition applies especially in the context of Samarinda, East Kalimantan, Indonesia.

\subsection{Paper Structure}

This paper is structured as follows: the first part comprises the introduction, research related to this study, and our contribution to this research. The second part includes a literature review of the variables used in this study. Part three carries the research methods used, while part four holds the results and discussion. Then, it ends with part five, which contains conclusions and recommendations for further research.

\section{BACKGROUND}

\subsection{Sharia Product}

Islamic financial institutions can take various forms, such as sharia commercial banks, sharia business units, sharia people's credit banks, or sharia cooperatives, in addition to sharia insurance and other similar companies. These Islamic financial institutions hold on a financial contract basis and sharia principles [11]. Thus, the products of Islamic financial institutions are essentially based on the principles of ijarah, murabahah, mudharabah, and musharaka [1]. Salam and ishtishna are some of the well-known products [11]. Each of these products has its own criteria.

The use of the profit-sharing principle has been applied since the beginning of the development of Islamic financial institutions, and this principle is then reviewed and adapted to modern business circumstances [12]. Therefore, knowledge about products that exist in Islamic financial institutions is very important for people to understand each product and can choose them properly [2].

\subsection{Job Type}

Job is a person's status in everyday life with the aim of earning income. Research from [2] states that one's job has a significant influence on his knowledge of banking products. An Islamic bank employee has positive perceptions about the practices, goals, and development of Islamic banks [13], [14]. However, as stated by [6], an ordinary farmer may not have sufficient knowledge about what is needed to obtain financing. In other words, he is 
less aware of banking products. Another study states that the type of job has a significant influence on people's perceptions of Islamic banking [15]. In fact, [2] states that the better the community's field of work, the higher their knowledge related to Islamic banking products.

Thus, the proposed hypothesis is:

H1: Job type has an effect on knowledge about Islamic financial institution products.

\subsection{Smartphone Use}

The use of smartphones is allegedly able to reduce productivity at work, especially if it is already at the level of addiction [16]. However, other researchers state that mobile internet, accessed through, one of which, smartphones, can increase worker productivity [17].

The smartphone is used for various things, such as social and non-social activity, as stated by [10] that the elderly in Australia use smartphones to access social media and also to read the news. In addition, [18] argues that the use of smartphones in the workplace can be classified into three parts: developing autonomy, strengthening relationships with colleagues and superiors, and increasing knowledge sharing. In the context of increasing knowledge sharing, we can use smartphones to search for information and to explain products both to bank customers and prospective clients [8]

Thus, the proposed hypotheses are:

H2: Job type affects the use of smartphones.

H3: Smartphones have an effect on knowledge about Islamic financial institution products.

\subsection{Religion}

Research from [4] states that religion does not moderate the relationship between relative advantage, compatibility, and complexity on the desire to use Islamic retail banks, but it remains a driving factor for using Islamic retail banks.

The study from [19] states that Muslim students have better financial knowledge compared to non-Muslim students. This is because of the education they receive from childhood. In addition, [20] states that in the Malaysian context, Muslim and non-Muslim communities both want Islamic banking products.

Thus, the proposed hypothesis is:

H4: Religion moderates the relationship between job type and knowledge about Islamic financial institution products.

\subsection{Framework}

As can be seen in Figure 2, the type of work is suspected to affect knowledge about Islamic financial institution products, and the use of smartphones may be a bridge to increase public knowledge, with various types of professions, on products of Islamic financial institutions. Besides, religion is also suspected of being able to strengthen the awareness of the public, who have various professions, on the products of Islamic financial institutions.

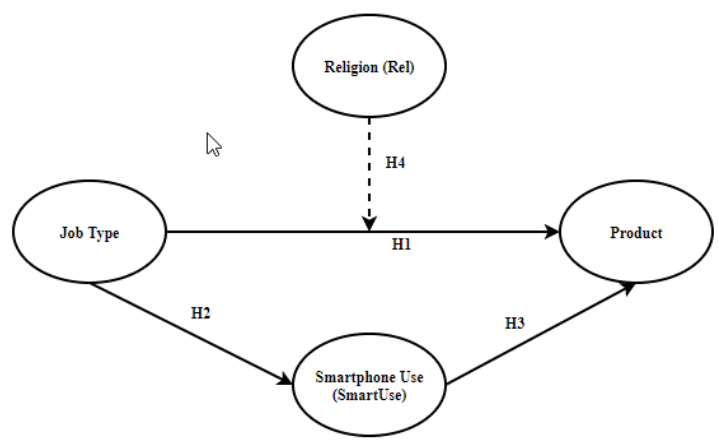

Figure 2 Conceptual Framework

\section{RESEARCH METHODS}

This research used a quantitative approach. The population in this study was Samarinda people from various professions including students and university students. The research instrument in the form of a questionnaire was distributed through Google forms and resulted in 121 responses. This sample size is much larger than the minimum sample size required by PLS-SEM according to the approach of [21], which is ten times the relationship that occurs in latent indicators (30 samples) or on the constructs of existing latent variables (40 samples). The data were processed using the partial least square approach considering that it can give good results even though the number of samples is not too large and the data are randomly distributed. Each question on the questionnaire was adapted from previous research, as shown in the following table:

Table 1. Constructs of questionnaire

\begin{tabular}{|l|l|l|}
\hline Construct & \#item & Source \\
\hline $\begin{array}{l}\text { Financial } \\
\text { Product }\end{array}$ & 3 & Salman \& Nawaz (2018) \\
\hline Job Type & 1 & Hasyid \& Salam (2015) \\
\hline $\begin{array}{l}\text { Smartphone } \\
\text { usage }\end{array}$ & 1 & Jocom (2013) \\
\hline Religion & 1 & Sabri \& Falahati (2014) \\
\hline
\end{tabular}




\section{RESULTS AND DISCUSSION}

Although not all goodness of fit measures meet the requirements, eight tests are declared fit for further analysis.

Table 2. The Goodness of Fit Model

\begin{tabular}{|c|c|c|c|}
\hline Goodness of Fit & $p$-value & $\begin{array}{l}\text { cut-off } \\
\text { value }\end{array}$ & Comment \\
\hline $\begin{array}{l}\text { Average path } \\
\text { coefficient } \\
(A P C)=0.317, \\
P<0.001\end{array}$ & 0.142 & 0.027 & Fit \\
\hline $\begin{array}{l}\text { Average } \\
\text { squared } \\
(A R S)=0.3338, \\
P<0.001\end{array}$ & 0.064 & 0.118 & UnFit \\
\hline $\begin{array}{l}\text { Average adjusted } \\
\text { R-squared } \\
(\text { AARS) }=0.329, \\
P<0.001\end{array}$ & 0.049 & 0.147 & UnFit \\
\hline $\begin{array}{l}\text { Average block VIF } \\
(\mathrm{AVIF})=2.311, \\
\text { acceptable if }<= \\
5 \text {, ideally }<=3.3\end{array}$ & 1.158 & $<=3.3$ & Fit \\
\hline $\begin{array}{l}\text { Average full } \\
\text { collinearity VIF } \\
(\mathrm{AFVIF})=2.167, \\
\text { acceptable if }<= \\
\text { 5, ideally }<=3.3\end{array}$ & 1.088 & $<=3.3$ & Fit \\
\hline $\begin{array}{l}\text { Tenenhaus GoF } \\
(\text { GoF })=0.477, \\
\text { small }>=0.1, \\
\text { medium }>=0.25, \\
\text { large }>=0.36\end{array}$ & 0.250 & $>=0.25$ & $\begin{array}{l}\text { Medium } \\
\text { Fit }\end{array}$ \\
\hline $\begin{array}{l}\text { Sympson's } \\
\text { paradox ratio } \\
(\mathrm{SPR})=0.833, \\
\text { acceptable if >= } \\
0.7 \text {, ideally }=1\end{array}$ & 1.00 & $>=0.7$ & Fit \\
\hline $\begin{array}{l}\text { R-squared } \\
\text { contribution ratio } \\
(\mathrm{RSCR})=0.998 \text {, } \\
\text { acceptable if >= } \\
0.9 \text {, ideally }=1\end{array}$ & 1.00 & $>=0.9$ & Fit \\
\hline
\end{tabular}

\begin{tabular}{|l|l|l|l|}
\hline Goodness of Fit & $p$-value & $\begin{array}{l}\text { cut-off } \\
\text { value }\end{array}$ & Comment \\
\hline $\begin{array}{l}\text { Statistical } \\
\text { suppression ratio } \\
\text { (SSR)=0.667, } \\
\text { acceptable if >= } \\
0.7\end{array}$ & 1.00 & $>=0.7$ & Fit \\
\hline $\begin{array}{l}\text { Nonlinear ratio } \\
\text { bivariate causality } \\
\text { direction } \\
\text { (NLBCDR)=0.833, } \\
\text { acceptable if >= } \\
0.7\end{array}$ & 1.00 & $>=0.7$ & Fit \\
\hline
\end{tabular}

The following table states whether the proposed hypotheses are supported by research data or not.

Table 3. Hypotheses

\begin{tabular}{|l|l|l|l|}
\hline Path (Hypothesis) & $\beta$ & $\begin{array}{l}p^{-} \\
\text {value }\end{array}$ & $\begin{array}{l}\text { Hypothesis } \\
\text { supported }\end{array}$ \\
\hline Job Type --> Product & -0.15 & $0.05^{\star}$ & Yes \\
\hline JobType --> SmartUse & -0.06 & $0.27^{\text {ns }}$ & No \\
\hline SmartUse --> Product & 0.14 & $0.06^{* *}$ & Yes \\
\hline $\begin{array}{l}\text { JobType*Rel --> } \\
\text { Product }\end{array}$ & 0.23 & $<0.01^{*}$ & Yes \\
\hline $\begin{array}{l}\text { Job Type } \rightarrow \text { SmartUse } \\
\rightarrow \text { Product }\end{array}$ & -0.61 & $0.53^{\text {ns }}$ & No \\
\hline
\end{tabular}

*significant at $\alpha=5 \%$; ** significant at $\alpha=10 \%$

This study states that job type has a negative and significant effect on knowledge about Islamic financial institution products $(\beta=-0.15$; $\mathbf{p}$-value $=0.05)$. besides, it does not affect smartphone use ( $\beta=-0.06 ; \mathrm{p}$-value $=0.27)$. The use of smartphones has no effect on knowledge about Islamic banking products at $\alpha=5 \%(\beta=-0.14$; $\mathrm{p}$ value $=0.06$ ), but it has an effect on knowledge of Islamic banking products at $\alpha=10 \%$. The results of the study also show that religion positively moderates the relationship between job type and Islamic financial institution products awareness $(\beta=-0.19$; $\mathrm{p}$-value $<0.01)$, but the use of smartphones does not mediate the relationship between the two $(\beta=-0.61 ; \mathrm{p}$-value $=0.53)$. 


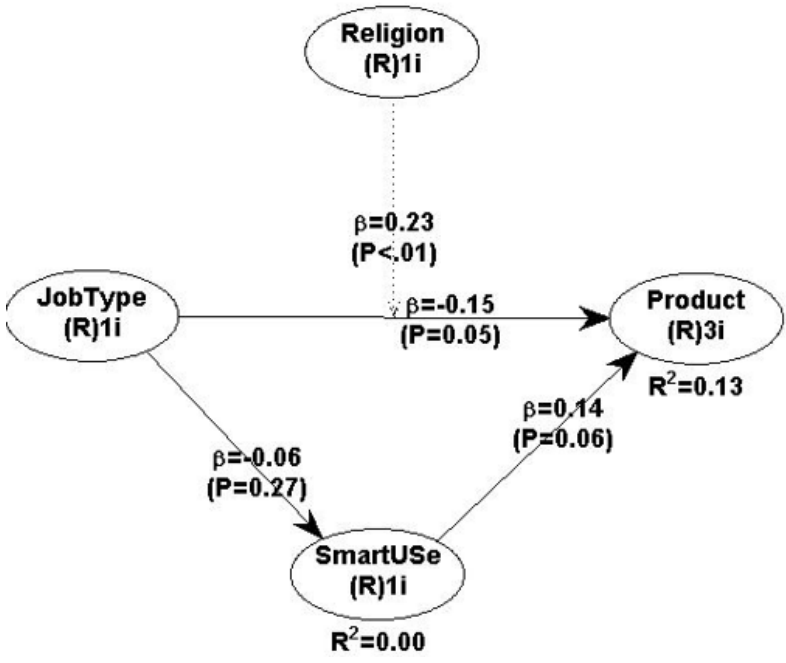

Figure 3 Hypotheses

The value of $\mathrm{R}^{2}$ explains that the variation of changes in knowledge of banking products can be explained by the job type and the use of smartphones by $13 \%$. Although this value is not too large, it can still be used as a basis for prediction because it is still above the cut-off value of 0.02 , and there is no need to revise this variable (Kock, 2020).

The community's job types do not seem to provide access to products of Islamic financial institutions, where the results of the study state that the more diverse the work of the community, the less knowledge they possess about Islamic financial institution products. The reason that can be given for this condition is that the respondent's work may not provide sufficient space for dealing with Islamic financial institutions. This result is inversely proportional to the result obtained by [15]. On the other hand, it indirectly supports [13] and [14] which state that work related to Islamic financial institutions will provide a positive perception of Islamic banking practices.

Religion can play a role by providing knowledge about muamalah, an activity that regulates human beings' matters. This knowledge sharing can be conducted in places of worship, such as mosques or surau, as the center of the development of religious studies. The Kyai, someone who has high religious knowledge (Islam), actions, and morals, must of course provide this teaching, besides learning about prayer, reading the Qur'an, and other similar knowledge. Thus, public awareness of the importance of Islamic financial institutions and their products can be increased. This result follows [19], who argue that Muslim students have better financial knowledge than non-Muslim students.

The smartphone, which is expected to provide information about Islamic banking, also has no impact on the awareness of Islamic financial institution products. The result of this study is not in line with the opinion of [18], which states that the use of smartphones can increase knowledge sharing. However, we agree with [8], which explains that introducing products from Islamic financial institutions can be done through smartphones.
One of the products that can be accessed by smartphones is mobile banking. Therefore, banks should increase the role of mobile banking, not only for conducting transactions but also as a tool for Islamic finance education. This education is aimed at all levels of society, not only for the bank's customers. Thus, smartphone users can access this information and obliquely, can increase public financial knowledge, especially related to Islamic financial institution products.

\section{CONCLUSION}

This study tries to realize the relations between job type, smartphone usage, religion, and financial institution product awareness. This study shows the role of religion in increasing public knowledge of Islamic financial institution products. Based on the analysis results, religion turns out to have an essential role in increasing people's financial knowledge. In contrast, the use of smartphones does not have an inherent role in this study. The respondent's type of work also does not provide an opportunity to distinguish more about the products of Islamic financial institutions.

Theoretically, the inquiry provides a new view related to the role of religion in everyday life. Religion here plays a role in guiding a person in the life of worship to Allah and influences one's financial knowledge, especially in Islamic finance.

This research implies that currently, Islamic financial institutions act as an intermediary institution; they must be able to act as an institution that can increase public financial knowledge. It can be done by optimizing the existing mobile banking services with information about Islamic financial products, especially in the context of East Kalimantan. In addition, the role of Kyai, who has religious knowledge, is crucial to increase public financial knowledge in general, especially of Islamic financial institution products.

The limitations faced in this study include the relatively small data. For further research, it is highly recommended to increase the number of samples, for example, to find out how millennial Muslims with higher education perceive the products of Islamic financial institutions or to know the role of Kyai in Islamic education, especially those related to Islamic finance.

\section{ACKNOWLEDGMENTS}

This research was supported by P3M POLBAN through the POLBAN postgraduate research scheme.

\section{REFERENCES}

[1] A. Salman and H. Nawaz, "Islamic financial system and conventional banking: A comparison," Arab Econ. Bus. J., vol. 13, no. 2, pp. 155-167, 2018, doi: 10.1016/j.aebj.2018.09.003. 
[2] M. Hasyim and A. Salam, "Analisis Pengaruh Pendidikan dan PEkerjaan terhadap Pengetahuan Produk Perbankan Syariah," J. Ekon. Syariah Indones., vol. V, no. 1, pp. 79-91, 2015.

[3] Mursyid, "Preferensi masyarakat kota samarinda terhadap bank syariah," Nalar Fiqh, vol. 3, no. 1, pp. 33-56, 2011.

[4] S. Thambiah, H. Ismail, E. M. Ahmed, and A. A. Khin, "Islamic Retail Banking Adoption in Malaysia: The Moderating Effect of Religion and Region," Int. J. Appl. Econ. Financ., vol. 7, no. 1, pp. 37-48, 2013.

[5] R. R. Rehman and H. M. Shoaib, "Employee Perception, Knowledge and Potential of Islamic Banking in Pakistan," J. Islam. Econ. Bank. Financ., vol. 10, no. 4, pp. 89-101, 2014.

[6] E. Wulandari, M. P. M. Meuwissen, M. H. Karmana, and A. G. J. M. Oude Lansink, “Access to finance from different finance provider types: Farmer knowledge of the requirements," PLoS One, vol. 12, no. 9, pp. 1-15, 2017, doi: 10.1371/journal.pone.0179285.

[7] Intan Trivena Maria Daeng, N. . Mewengkang, and E. R. Kalesaran, "Penggunaan Smartphone Dalam Menunjang Aktivitas Perkuliahan Oleh Mahasiswa Fispol Unsrat Manado Oleh," e-journal "Acta Diurna," vol. 6, no. 1, pp. 1-15, 2017.

[8] N. Jocom, "Peran Smartphone Dalam Menunjang Kinerja Karyawan Bank Prismadana (Studi Pada Karyawan Bank Prismadana Cabang Airmadidi)," Acta Diurna, vol. 1, no. 1, pp. 1-24, 2013.

[9] A. A. F. AlZwamri and N. Hussain, "The Impact of Smartphones on Work Productivity as Perceived by Employees at a Goverment Department in Salalah, Oman," J. Islam. Soc. Sci. Humanit., vol. x, no., p. xx, 2017.

[10] P. A. Busch, G. I. Hausvik, O. K. Ropstad, and D. Pettersen, "Smartphone usage among older adults," Comput. Human Behav., vol. 121, p. 106783, Aug. 2021, doi: 10.1016/j.chb.2021.106783.

[11] K. Aljifri and S. K. Khandelwal, "Financial Contracts in Conventional and Islamic Financial Institutions: an Agency Theory Perspective," Rev. Bus. Financ. Stud., vol. 4, no. 2, pp. 79-89, 2013, [Online]. Available: https://papers.ssrn.com/sol3/papers.cfm?abstract_i $\mathrm{d}=2263337$.
[12] A. R. Samsudin, "Product Innovation of Islamic Financial Institutions," Int. J. Nusant. Islam, vol. 4, no. $1, \quad$ pp. 29-40, 2016, doi: 10.15575/ijni.v4i1.1186.

[13] B. A. Shah, G. S. Khan Niazi, and A. Majid, "Employees' Perceptions about Islamic Banking and its Growth Potential in Pakistan," Bus. Econ. Rev., vol. 8, no. 1, pp. 53-76, 2016, doi: 10.22547/ber/8.1.4.

[14] I. Buchari, A. Rafiki, and M. A. H. Al Qassab, "Awareness and Attitudes of Employees towards Islamic Banking Products in Bahrain," Procedia Econ. Financ., vol. 30, no. 15, pp. 68-78, 2015, doi: 10.1016/s2212-5671(15)01256-3.

[15] S. Rahmany and Y. Asnita, "Pengaruh Pendidikan, Profesi Dan Bagi Hasil Terhadap Persepsi Masyarakat Pada Perbankan Syariah," JPS (Jurnal Perbank. Syariah), vol. 1, no. 1, pp. 69-84, 2020, doi: 10.46367/jps.v1i1.203.

[16] É. Duke and C. Montag, "Smartphone addiction, daily interruptions and self-reported productivity," Addict. Behav. Reports, vol. 6, pp. 90-95, Dec. 2017, doi: 10.1016/j.abrep.2017.07.002.

[17] I. Bertschek and T. Niebel, "Mobile and more productive? Firm-level evidence on the productivity effects of mobile internet use," Telecomm. Policy, vol. 40, no. 9, pp. 888-898, Sep. 2016, doi: 10.1016/j.telpol.2016.05.007.

[18] T. Pitichat, "Smartphones in the workplace: Changing organizational behavior, transforming the future," Lux, vol. 3, no. 1, pp. 1-10, 2013, doi: 10.5642/lux.201303.13.

[19] M. F. Sabri and L. Falahati, "Toward a Framework of Financial Wellness Determinants: Investigating the Moderating Effect of Religion," Aust. J. Basic Appl. Sci., vol. 8, no. 9, pp. 275-281, 2014.

[20] N. A. Zainordin, M. Selvaraja, N. Yee Man, and L. Soon Hong, "Challenges and Opportunities of Islamic Banking and Financial Institutions in Malaysia," South East Asia J. Contemp. Business, Econ. Law, vol. 10, no. 1, p. pp.1-30, 2016.

[21] J. F. Hair, C. M. Ringle, and M. Sarstedt, "PLSSEM: Indeed a silver bullet," J. Mark. Theory Pract., vol. 19, no. 2, pp. 139-152, 2011, doi: 10.2753/MTP1069-6679190202. 